\title{
Penampilan, Kualitas Kimia, dan Off-Odor Daging Itik (Anas plathyrynchos) yang Diberi Pakan Mengandung Beluntas (Pluchea indica L. Less)
}

\author{
Performance, Chemical Quality, and Off-Odor of Duck's Meat (Anas plathyrynchos) Fed Beluntas \\ (Pluchea indica L. Less) Containing Ration
}

\author{
Rukmiasih $^{\mathrm{a} * \#, \text { P. S. Hardjosworo }}{ }^{\mathrm{z}}$, , W. G. Piliang ${ }^{\sharp}$, , J. Hermanianto ${ }^{\mathrm{d}}$, \& A. Apriyantono ${ }^{\mathrm{d}}$ \\ aProgram Studi Ilmu Ternak, Sekolah Pascasarjana, Institut Pertanian Bogor \\ bDepartemen Ilmu Produksi dan Teknologi Peternakan, Fakultas Peternakan, Institut Pertanian Bogor \\ 'Departemen Ilmu Nutrisi dan Teknologi Pakan, Fakultas Peternakan, Institut Pertanian Bogor \\ ${ }^{\sharp} J$ ln. Agatis, Kampus IPB Darmaga Bogor 16680 \\ dDepartemen Ilmu dan Teknologi Pangan, Fakultas Teknologi Pertanian, Institut Pertanian Bogor \\ Jln. Kamper, Kampus IPB Darmaga Bogor 16680 \\ (Diterima 26-01-2010; disetujui 26-04-2010)
}

\begin{abstract}
Duck meat is not preferred because its off-odor. Its off-odor is caused by lipid oxidation which preventable by antioxidant. Beluntas has antioxidant and anti nutrition. This research was designed to know the level of beluntas and feeding duration on performance, chemical, and duck's meat offodor. Beluntas was given to 108 culling ducks, about 12 months old. The research used a completely randomized design with $3 \times 3$ factorial models, with 3 replicates. The factors were different levels of beluntas $(0 \%, 1 \%$, and $2 \%)$ in the ration, and feeding duration of each ration $(3,5$, and 7 weeks). The data collected were analyzed using analysis of variance and Tukey's test. The results showed that no interaction was found between the two factors. Beluntas did not affect duck's performance. Feeding duration of each ration affected the fat and fatty acid content $(P<0.01)$ and TBARS (thiobarbituric reactive subtances) value of the meat with skin $(\mathrm{P}<0.05)$. Beluntas level at $1 \%$ increased $\mathrm{C} 18: 0(\mathrm{P}<0.05)$ and total $(\mathrm{C} 18: 2$ and $\mathrm{C} 18: 3)(\mathrm{P}<0.052)$. Beluntas levels at $1 \%$ and $2 \%$ reduced $(\mathrm{P}<0.01)$ duck's meat off-odor and increased $(\mathrm{P}<0.05)$ consumers preference. This research concluded that the inclusion of $1 \%$ beluntas for 3 weeks was effective to reduce duck's meat off-odor without negative impact on performance.
\end{abstract}

Key words: duck, off-odor, beluntas (Pluchea indica L.), fat

\section{PENDAHULUAN}

Itik merupakan salah satu unggas air. Sebagai unggas air, ternak ini memiliki kulit yang tebal yang disebabkan oleh adanya lapisan lemak tebal yang terdapat di lapisan bawah kulit. Daging itik dibanding spesies unggas lainnya (itik, ayam, kalkun), mengandung lemak yang lebih tinggi. Lemak unggas, pada umumnya sebagian besar terdiri atas asam lemak tidak jenuh (Pisulewski, 2005). Daging itik mengandung asam lemak tidak jenuh yang tinggi dan pigmen haematik yang tinggi. Asam lemak tidak jenuh merupakan bahan yang mudah mengalami otooksidasi (Muika et al., 2005) dan pigmen haematik dalam daging dapat mempercepat laju oksidasi lemak (Tang et al., 2000; Barciela et al., 2008; Min

*Korespondensi:

Departemen Ilmu dan Teknologi Peternakan, Fakultas Peternakan, IPB Jln. Agatis, Kampus IPB Darmaga Bogor 16680

e-mail: asihipb08@yahoo.com et al., 2010; Yoon et al., 2010). Kondisi ini memungkinkan oksidasi pada daging itik lebih tinggi dari pada daging ayam.

Oksidasi asam lemak tidak jenuh merupakan reaksi utama yang bertanggung jawab atas terjadinya degradasi lemak, yang diawali dengan terbentuknya radikal bebas. Terbentuknya radikal bebas mengakibatkan timbulnya peroksida-peroksida yang bila mengalami dekomposisi akan menghasilkan zat-zat kimia (Márquez-Ruiz et al., 2008) yang berbau khas. Bau khas pada daging itik, bau amis, sebagian besar adalah hasil proses oksidasi lemak (Hustiany, 2001). Oleh karena itu perlu dicari upaya untuk mencegah terjadinya oksidasi lemak yang dapat menyebabkan bau (off-odor) pada daging itik tersebut. Beberapa penelitian menunjukkan bahwa oksidasi lemak pada daging, dapat dicegah dengan menggunakan antioksidan (Zielińska et al., 2001; Hernandez et al., 2004).

Beluntas (Pluchea indica L. Less) merupakan salah satu tanaman herbal yang mengandung flavonoid (Widyawati, 2004), polifenol, dan vitamin C (Traithip, 
2005). Flavonoid mempunyai aktivitas sebagai antioksidan (Panovskai et al., 2005). Senyawa polifenol mempunyai aktivitas sebagai antioksidan (Huda-Faujan et al., 2007; Huda-Faujan et al., 2009), yang bersama-sama dengan vitamin $\mathrm{C}$ dan karotenoid melindungi jaringan tubuh dari kerusakan akibat stres oksidatif (Scalbert \& Williamson, 2000). Namun demikian, beluntas juga mengandung zat anti nutrisi tanin. Tanin dalam pakan dengan level $0,5 \%$ atau lebih menyebabkan penurunan pertumbuhan, ketersediaan energi pakan dan protein, kematian lebih dari $4 \%$, serta menghambat aktivitas enzim (tripsin, amilase dan lipase) atau sistem enzim (Johri, 2005). Penelitian ini dilakukan untuk mengkaji respon biologis ternak itik terhadap beluntas dan efektivitas daun beluntas dalam mengurangi bau (off-odor) daging itik melalui pakan yang diberikan.

\section{MATERI DAN METODE}

\section{Materi}

Penelitian ini menggunakan itik lokal afkir sebanyak 108 ekor. Itik-itik tersebut merupakan itik betina dewasa yang berumur sekitar 1 tahun. Ternak dipelihara di Laboratorium Ilmu Produksi Ternak Unggas, Fakultas Peternakan, Institut Pertanian Bogor. Bobot hidupnya berkisar antara 1.302,4-1.312,3 g.

Daun beluntas diperoleh dari daerah Bogor. Tanaman ini diambil sepanjang $50 \mathrm{~cm}$ dari pucuk sampai batang, kemudian diambil daunnya dan dikeringkan. Pengeringan dilakukan dengan diangin-anginkan pada suhu kamar selama 2 hari, kemudian dioven pada suhu 55-60 ${ }^{\circ} \mathrm{C}$ selama 2-3 jam sampai renyah untuk digiling.

Kandungan vitamin C dan beta karoten beluntas hasil penggilingan dianalisa di Laboratorium Pascapanen Balai Besar Penelitian dan Pengembangan Pascapanen Pertanian, Badan Penelitian dan Pengembangan Pertanian, Departemen Pertanian-Bogor dan kandungan fitokimianya (total fenol, flavonoid, tanin, tanin terkondensasi, dan terhidrolisis) di Laboratorium Kimia Makanan, Departemen Kesehatan, Badan Penelitian dan Pengembangan Gizi, Bogor. Kandungan fitokimia, seperti total fenol dianalisa menggunakan metode Chandler \& Dodds yang dimodifikasi oleh Shetty et al. (1995) dengan spektrofotometer, flavonoid diukur mengikuti prosedur yang disusun Miean \& Mohammed (2001) dengan high performance liquid chromatography (HPLC). Total tanin diukur menggunakan metode Burns dengan spektrofotometer, dan tanin terkondensasi/terhidrolisis menggunakan HPLC menurut prosedur analisis Stamet et al. (1990).

Pakan komersial digunakan sebagai ransum basal dengan $0 \%$ daun beluntas sebagai kontrol, sedangkan pakan perlakuan lainnya adalah pakan dengan $1 \%$ daun beluntas dan pakan dengan $2 \%$ daun beluntas. Ketiga macam pakan perlakuan tersebut dianalisa kandungan nutrisinya menggunakan analisis proksimat termasuk energi brutonya di Laboratorium Ilmu Nutrisi dan Teknologi Pakan, Fakultas Peternakan, Institut Pertanian Bogor

Itik dipelihara dalam kandang berupa boks berukuran 100x100x60 $\mathrm{cm}^{3}$. Masing-masing kandang diisi 4 ekor itik. Tempat pakan dan air minum disediakan di dalam kandang. Kebersihan di dalam kandang selalu dipelihara.

\section{Metode}

Sebelum dimasukkan ke dalam kandang, itik disemprot obat kutu, diberi obat cacing (triple worm) sebanyak satu kaplet per ekor. Itik diberi kesempatan beradaptasi dengan lingkungan baru serta pakan yang mengandung daun beluntas berturut-turut selama satu minggu. Pakan dan air minum diberikan ad libitum. Pemotongan itik dilakukan pada setiap akhir pemeliharaan, yaitu setelah 3, 5, dan 7 minggu pemberian pakan perlakuan. Sebelum pemotongan, itik dipuasakan dari pakan selama 6 jam, kemudian dipotong, dicelup dalam air panas, dibului, dikeluarkan jeroannya, dipisahkan daging dada dan paha beserta kulitnya, dan segera dibekukan. Daging dada dan paha dengan kulit (beku) bagian kiri dari semua itik per ulangan (4 ekor) dikomposit, digiling sampai homogen, kemudian disimpan dalam freezer untuk analisa komposisi gizi, asam lemak, nilai thio barbituric acid reactive subtances (TBARS), dan sensori.

Peubah yang diamati adalah: a) penampilan itik, b) komposisi gizi daging (dada dan paha dengan kulit) yang meliputi kadar air, kadar protein (metode Kjeldahl), dan kadar lemak (metode Soxhlet) (AOAC, 1984), c) komposisi asam lemak daging dan kulit itik dilakukan dengan cara mengekstraksi lemak, melakukan metilasi untuk memperoleh ester metil dari asam lemak kemudian dianalisa lebih lanjut dengan GC (IUPAC, 1988), d) nilai TBARS (tingkat laju oksidasi lemak) daging dengan kulit itik mengikuti prosedur Laboratorium Kimia Pangan, Fakultas Teknologi Pertanian, Institut Pertanian Bogor, e) sensori daging itik dengan kulit (Meilgaard et al., 1999). Uji sensori dilakukan untuk mempelajari tingkat bau (off-flavor) daging itik dengan kulit hasil perlakuan. Uji ini dilakukan oleh panelis terlatih yang diperoleh melalui beberapa tahapan, yaitu perekrutan dan seleksi panelis, pelatihan, penyiapan sampel dan pengujian sampel oleh panelis. Selain dilakukan uji sensori terhadap tingkat bau daging itik dengan kulit, juga dilakukan uji hedonik. Uji hedonik dilakukan oleh 111 orang panelis tidak terlatih. Panelis diminta untuk menyatakan kesukaan atau ketidaksukaannya terhadap bau daging dan kulit itik akibat perlakuan dengan 7 skala hedonik yaitu $1=$ sangat tidak suka; $2=$ tidak suka; $3=$ agak tidak suka; $4=$ netral; $5=$ agak suka; $6=$ suka; $7=$ sangat suka.

\section{Rancangan Percobaan dan Analisis Data}

Penelitian dilakukan dengan menggunakan rancangan acak lengkap pola faktorial. Faktor pertama adalah level pemberian beluntas, yaitu $0 \%, 1 \%$, dan $2 \%$. Faktor kedua adalah lama pemberian pakan, yaitu selama 3, 5, dan 7 minggu. Masing-masing perlakuan terdiri atas 3 ulangan dan masing-masing ulangan terdiri atas 4 ekor itik. Data yang diperoleh dianalisa menggunakan ANOVA dan uji lanjut Tukey's menurut Mattjik \& Sumertajaya (2002). 


\section{HASIL DAN PEMBAHASAN}

\section{Kandungan Gizi Pakan Perlakuan dan Beluntas}

Kandungan nutrisi pakan perlakuan adalah iso protein dan iso kalori (Tabel 1). Kandungan vitamin dan zat fitokimia tepung daun beluntas terdapat pada Tabel 2. Daun beluntas kering mengandung tanin sebesar 1,88\%. Tanin merupakan polimer polifenol yang mempunyai kapasitas membentuk kompleks dengan karbohidrat dan protein. Tanin merupakan salah satu zat antinutrisi. Berdasarkan hasil analisis, daun beluntas kering mengandung fenol sebesar 9,85\% dan flavonoid sebesar $4,47 \%$.

Beberapa polifenol asal tanaman mempunyai kemampuan sebagai antioksidan, yaitu melindungi sel dari kerusakan oksidatif (Young et al., 2003) dengan cara menetralkan oksidan reaktif (Moskaug et al., 2005; Kruawan \& Kangsadalampai, 2006; Savatović et al., 2008; Ahmed \& Beigh, 2009). Beberapa senyawa fenol alam telah diketahui strukturnya dan flavonoid merupakan golongan terbesar. Flavonoid mempunyai kemampuan sebagai antioksidan (Beecher, 2003; Zang \& Hamauzu, 2003). Senyawa flavonoid kelompok flavonol, terutama terdiri atas kuersetin, mirisetin, dan kamperol (Lin et al.,

Tabel 1. Kandungan nutrisi pakan perlakuan

\begin{tabular}{lrrr}
\hline \multirow{2}{*}{ Nutrisi pakan } & \multicolumn{3}{c}{ Level pemberian beluntas } \\
\cline { 2 - 4 } & \multicolumn{1}{c}{$0 \%$} & \multicolumn{1}{c}{$1 \%$} & \multicolumn{1}{c}{$2 \%$} \\
\hline Energi bruto & $3.984,00$ & $3.983,00$ & $3.777,00$ \\
(kkal/kg) & 86,50 & 85,33 & 86,62 \\
Bahan kering (\%) & 17,15 & 17,46 & 17,86 \\
Protein kasar (\%) & 3,55 & 3,62 & 3,72 \\
Serat kasar (\%) & 4,02 & 4,03 & 3,90 \\
Lemak kasar (\%) & 50,10 & 50,35 & 50,01 \\
BETN (\%) & 11,68 & 9,87 & 11,13 \\
Abu (\%) & 4,54 & 4,82 & 4,56 \\
Ca (\%) & 0,54 & 0,55 & 0,48 \\
P (\%) & & &
\end{tabular}

Tabel 2. Kandungan vitamin dan zat fitokimia daun beluntas kering

\begin{tabular}{lc}
\hline \multicolumn{1}{c}{ Zat fitokimia } & Jumlah \\
\hline Vitamin & \\
Vitamin C (mg/100g) & 98,25 \\
Beta karoten (mg/100g) & 2552 \\
Fitokimia & \\
Total tanin (\%) & 1,88 \\
Total fenol (\%) & 9,85 \\
Total flavonoid (\%) & 4,47 \\
Kuersetin (\%) & 1,45 \\
Mirisetin (\%) & 1,58 \\
Kaemperol (\%) & 0,80 \\
\hline
\end{tabular}

2006). Kuersetin (Kahkonen \& Heinonen, 2003; Moskaug et al., 2005) mempunyai aktivitas antioksidan yang tinggi.

Selain flavonoid, beluntas juga mengandung vitamin C dan beta karoten. Vitamin C dikenal sebagai antioksidan karena kemampuannya mendonorkan elektron (Padayatty et al., 2003) yang dapat mencegah kerusakan sel dari oksidasi lemak (Evans, 2000). Beta karoten mempunyai aktivitas sebagai antioksidan (Kiokias \& Gordon, 2004), melindungi sel dari stres oksidatif yang diinduksi oleh Fe (Matos et al., 2006). Kandungan flavonoid menempati jumlah tertinggi dari ketiga jenis antioksidan tersebut. Berdasarkan analisis fitokimia tersebut dapat dinyatakan bahwa beluntas dapat dijadikan sebagai sumber antioksidan.

\section{Penampilan Itik}

Rataan konsumsi pakan itik per ekor per hari berkisar 156-160 g dan pemberian beluntas dalam pakan sampai $2 \%$ tidak menunjukkan adanya penurunan palatabilitas pakan. Pengaruh perlakuan terhadap penampilan itik terdapat pada Tabel 3. Interaksi antara level pemberian beluntas dengan lama pemberian pakan perlakuan terhadap semua peubah penampilan itik, tidak nyata. Bobot badan awal itik untuk semua perlakuan seragam/tidak berbeda nyata (Tabel 3). Penambahan $1 \%$ dan $2 \%$ beluntas dalam pakan tidak berpengaruh terhadap penampilan itik yang dipelihara, artinya bobot badan, pertambahan bobot badan (PBB) dan persentase lemak abdomen itik yang mendapat beluntas $1 \%$ dan $2 \%$ tidak berbeda dengan kontrol (tanpa beluntas).

Makin lama waktu pemberian pakan, bobot badan, dan PBB itik meningkat. Bobot badan dan PBB itik pada pemberian pakan perlakuan selama 7 minggu nyata $(\mathrm{P}<0,05)$ lebih besar daripada bobot badan dan PBB itik pada perlakuan selama 3 dan 5 minggu, sedangkan antara lama pemberian pakan perlakuan 3 dan 5 minggu tidak berbeda. Pertambahan bobot badan yang lebih besar ini disebabkan karena asupan pakan yang diterima itik lebih lama (7 minggu), dan ruang geraknya yang kurang. Hal ini berarti dibutuhkan waktu 4 minggu untuk mendapatkan bobot badan akhir yang lebih tinggi. Persentase lemak abdomen terhadap bobot badan akhir itik pada lama pemberian pakan selama 7 minggu nyata $(P<0,05)$ lebih tinggi daripada perlakuan 3 dan 5 minggu. Persentase lemak abdomen itik pada lama pemberian pakan perlakuan 3 dan 5 minggu tidak berbeda nyata.

Itik yang mendapat pakan perlakuan selama 3, 5, dan 7 minggu berturut-turut mencapai umur sekitar 56, 58, dan 60 minggu dan itik-itik tersebut tidak lagi menghasilkan telur. Pemeliharaan dalam boks (4 ekor per boks berukuran satu meter persegi) membatasi aktivitas gerak itik-itik tersebut, sehingga nutrisi dan energi yang didapat dari pakan tidak lagi digunakan untuk memproduksi telur maupun aktivitas gerak. Kombinasi umur makin tua, ruang gerak terbatas dan tidak lagi bertelur memacu peningkatan perlemakan, terutama lemak abdominal (Tabel 3). Hal ini menyebabkan peningkatan bobot badan dan bobot badan akhir pada itik 
Tabel 3. Penampilan itik (Anas plathyrynchos) pada level pemberian beluntas dan lama pemberian pakan yang berbeda

\begin{tabular}{|c|c|c|c|c|c|}
\hline \multirow{2}{*}{ Peubah } & \multirow{2}{*}{$\begin{array}{l}\text { Lama pemberian } \\
\text { pakan perlakuan } \\
\text { (minggu) }\end{array}$} & \multicolumn{3}{|c|}{ Level pemberian beluntas } & \multirow{2}{*}{ Rataan } \\
\hline & & $0 \%$ & $1 \%$ & $2 \%$ & \\
\hline \multirow{4}{*}{$\begin{array}{l}\text { Bobot badan awal } \\
\text { (g/ekor) }\end{array}$} & 3 & $1.311,4 \pm 4,3$ & $1.305,3 \pm \quad 5,5$ & $1.307,4 \pm 3,5$ & $1.308,0 \pm 3,1$ \\
\hline & 5 & $1.312,3 \pm 7,2$ & $1.310,1 \pm \quad 5,8$ & $1.310,4 \pm 7,1$ & $1.310,9 \pm 1,2$ \\
\hline & 7 & $1.305,9 \pm 3,6$ & $1.303,4 \pm \quad 9,9$ & $1.307,3 \pm 3,5$ & $1.305,5 \pm 2,0$ \\
\hline & Rataan & $1.309,9 \pm 3,4$ & $1.306,2 \pm \quad 3,5$ & $1.308,4 \pm 1,8$ & \\
\hline \multirow{4}{*}{$\begin{array}{l}\text { Bobot badan akhir } \\
\text { (g/ekor) }\end{array}$} & 3 & $1.391,8 \pm 24,2$ & $1.369,8 \pm 20,8$ & $1.369,5 \pm 20,3$ & $1.377,1 \pm 12,8^{\mathrm{a}}$ \\
\hline & 5 & $1.445,3 \pm 40,0$ & $1.386,2 \pm 142,0$ & $1.435,4 \pm 41,2$ & $1.422,3 \pm 31,7^{\mathrm{a}}$ \\
\hline & 7 & $1.529,2 \pm 73,9$ & $1.492,6 \pm 72,0$ & $1.483,3 \pm 51,5$ & $1.501,7 \pm 24,3^{\mathrm{b}}$ \\
\hline & Rataan & $1.455,5 \pm 69,3$ & $1.416,2 \pm 66,6$ & $1.429,4 \pm 57,2$ & \\
\hline \multirow{4}{*}{$\begin{array}{l}\text { Pertambahan bobot } \\
\text { badan (g/ekor) }\end{array}$} & 3 & $80,4 \pm 25,5$ & $64,6 \pm 17,0$ & $62,1 \pm 20,2$ & $69,0 \pm 10,0^{\text {a }}$ \\
\hline & 5 & $133,1 \pm 38,8$ & $119,4 \pm 77,8$ & $125,0 \pm 35,5$ & $125,8 \pm 6,9^{\mathrm{a}}$ \\
\hline & 7 & $223,3 \pm 70,6$ & $189,2 \pm 79,9$ & $176,1 \pm 53,4$ & $196,2 \pm 24,4^{\mathrm{b}}$ \\
\hline & Rataan & $145,6 \pm 72,3$ & $124,4 \pm 62,5$ & $121,1 \pm 57,1$ & \\
\hline \multirow[t]{4}{*}{ Lemak abdomen $(\%)^{*}$} & 3 & $1,5 \pm 0,1$ & $2,2 \pm 0,3$ & $1,7 \pm 0,1$ & $1,8 \pm 0,3^{\mathrm{a}}$ \\
\hline & 5 & $2,3 \pm 0,4$ & $2,7 \pm 1,6$ & $2,6 \pm 1,1$ & $2,5 \pm 0,2^{\mathrm{ab}}$ \\
\hline & 7 & $2,4 \pm 1,2$ & $3,4 \pm 0,9$ & $3,1 \pm 0,3$ & $3,0 \pm 0,6^{b}$ \\
\hline & Rataan & $2,4 \pm 0,9$ & $2.8 \pm 0,6$ & $2,5 \pm 0,7$ & \\
\hline
\end{tabular}

Keterangan: superskrip berbeda pada kolom yang sama menunjukkan berbeda nyata $(\mathrm{P}<0,05) .{ }^{*}$ Persentase terhadap bobot badan akhir.

yang mendapat pakan perlakuan selama 7 minggu. Itik yang mendapat pakan perlakuan selama 3 minggu dan 5 minggu mengalami peningkatan perlemakan juga, tetapi tidak menyebabkan perbedaan bobot badan akhir dan PBB yang berarti.

Kandungan gizi daging itik. Tidak ada interaksi antara level pemberian beluntas dengan lama waktu pemberian pakan terhadap kandungan gizi daging itik yang dihasilkan. Tabel 4 menunjukkan bahwa level pemberian beluntas sebanyak $1 \%$ dan $2 \%$ tidak berpengaruh terhadap kandungan gizi (air, protein, dan lemak) daging itik dengan kulit. Kandungan air dan protein daging itik dengan kulit pada lama pemberian pakan 7 minggu nyata $(\mathrm{P}<0,05)$ lebih rendah daripada lama pemberian pakan 3 dan 5 minggu, sedangkan antara lama pemberian pakan 3 dan 5 minggu tidak berbeda. Sebaliknya, kandungan lemak daging itik dengan kulit pada lama pemberian pakan 7 minggu nyata $(\mathrm{P}<0,05)$ lebih tinggi daripada lama pemberian

Tabel 4. Nilai gizi daging dengan kulit itik segar (Anas plathyrynchos) pada level pemberian beluntas dan lama pemberian pakan berbeda

\begin{tabular}{|c|c|c|c|c|c|}
\hline \multirow{2}{*}{ Peubah } & \multirow{2}{*}{$\begin{array}{l}\text { Lama pemberian } \\
\text { pakan perlakuan } \\
\text { (minggu) }\end{array}$} & \multicolumn{3}{|c|}{ Level pemberian beluntas } & \multirow{2}{*}{ Rataan } \\
\hline & & $0 \%$ & $1 \%$ & $2 \%$ & \\
\hline \multirow{3}{*}{ Kadar air (\%) } & 3 & $62,00 \pm 0,46$ & $61,18 \pm 1,26$ & $59,48 \pm 3,43$ & $60,88 \pm 2,27^{a}$ \\
\hline & 5 & $59,13 \pm 2,36$ & $58,95 \pm 3,42$ & $58,37 \pm 2,36$ & $58,82 \pm 2,61^{\mathrm{a}}$ \\
\hline & 7 & $54,37 \pm 4,41$ & $53,13 \pm 3,74$ & $55,34 \pm 1,02$ & $54,28 \pm 3,32^{\mathrm{b}}$ \\
\hline Rataan & & $58,48 \pm 4,23$ & $57,75 \pm 4,50$ & $57,73 \pm 2,94$ & \\
\hline \multirow{3}{*}{$\begin{array}{l}\text { Kadar protein } \\
(\% / 100 \% \mathrm{BK})\end{array}$} & 3 & $35,51 \pm 6,10$ & $37,44 \pm 2,28$ & $37,73 \pm 8,15$ & $36,89 \pm 5,75^{b}$ \\
\hline & 5 & $40,52 \pm 2,97$ & $39,64 \pm 3,64$ & $38,62 \pm 3,20$ & $39,59 \pm 3,19^{b}$ \\
\hline & 7 & $27,70 \pm 4,77$ & $27,88 \pm 4,65$ & $31,01 \pm 3,92$ & $28,86 \pm 4,47^{\mathrm{a}}$ \\
\hline Rataan & & $34,58 \pm 6,46$ & $34,99 \pm 6,25$ & $35,79 \pm 4,16$ & \\
\hline \multirow{3}{*}{$\begin{array}{l}\text { Kadar lemak } \\
(\% / 100 \% B K)\end{array}$} & 3 & $38,92 \pm 3,33$ & $44,84 \pm 10,08$ & $42,20 \pm 9,65$ & $41,99 \pm 8,17^{\mathrm{a}}$ \\
\hline & 5 & $46,05 \pm 11,42$ & $47,41 \pm 21,54$ & $54,03 \pm 3,45$ & $49,16 \pm 13,83^{\mathrm{a}}$ \\
\hline & 7 & $57,53 \pm 11,85$ & $63,16 \pm 9,31$ & $65,50 \pm 8,54$ & $62,06 \pm 10,00^{\mathrm{b}}$ \\
\hline Rataan & & $47,50 \pm 9,39$ & $51,80 \pm 9,92$ & $53,91 \pm 11,65$ & \\
\hline
\end{tabular}

Keterangan: superskrip berbeda pada kolom yang sama menunjukkan berbeda nyata $(\mathrm{P}<0,05)$. 
pakan 3 dan 5 minggu, sedangkan kandungan lemak antara 3 minggu dengan 5 minggu tidak berbeda. Hal ini karena makin tuanya umur itik. Makin lama waktu pemberian pakan perlakuan, berarti makin tua umur ternak dan makin cepat terjadi lipogenesis. Hal ini sesuai dengan hasil penelitian Guo-Bin (2010) pada ayam lokal Cina umur lebih dari 8 minggu, kandungan lemak intramuskulernya makin tinggi dengan makin tuanya umur ternak. Rendahnya kandungan protein daging itik dengan kulit pada lama pemberian pakan perlakuan 7 minggu dapat terjadi karena sebagian protein dikonversi menjadi lemak.

Komposisi asam lemak. Interaksi antara level pemberian beluntas dengan lama pemberian pakan terhadap semua jenis asam lemak yang terdeteksi tidak berbeda nyata. Tabel 5 menunjukkan bahwa asam lemak jenuh daging itik dengan kulit yang mendapat beluntas pada umumnya lebih tinggi daripada kontrol, khususnya asam lemak stearat (C18:0) yang mendapat beluntas 1\% nyata $(\mathrm{P}<0,05)$ lebih tinggi daripada kontrol. Hal yang sama terjadi pada asam lemak tidak jenuh tunggal dan asam lemak tidak jenuh ganda. Asam lemak tidak jenuh ganda linoleat (C18:2) dan total asam lemak tidak jenuh ganda (ALTJG) yang merupakan asam lemak esensial daging itik dengan kulit yang mendapat beluntas $1 \%$ cenderung lebih tinggi $(\mathrm{P}<0,052)$ daripada kontrol. Hal ini menunjukkan adanya indikasi bahwa zat aktif yang terdapat pada beluntas dapat melindungi asam lemak (jenuh dan tidak jenuh) dari kerusakan akibat oksidasi (Zielińska et al., 2001), baik dengan cara menangkap radikal bebas, mengkelat ion logam transisi, maupun dengan menghambat kerja enzim prooksidan sebagaimana dikemukakan Schewe \& Sies (2003).

Tabel 5. Rataan kandungan asam lemak daging itik (Anas plathyrynchos) dengan kulit (\% terhadap bobot daging) pada level pemberian beluntas yang berbeda

\begin{tabular}{lccc}
\hline \multirow{2}{*}{$\begin{array}{l}\text { Jenis asam } \\
\text { lemak }\end{array}$} & \multicolumn{3}{c}{ Level pemberian beluntas } \\
\cline { 2 - 4 } & $0 \%$ & $1 \%$ & $2 \%$ \\
\hline C14:0 & $0,17 \pm 0,03$ & $0,19 \pm 0,06$ & $0,19 \pm 0,05$ \\
C16:0 & $5,97 \pm 1,45$ & $6,57 \pm 2,41$ & $6,48 \pm 1,53$ \\
C18:0 & $1,29 \pm 0,34^{\mathrm{a}}$ & $2,10 \pm 0,84^{\mathrm{b}}$ & $1,80 \pm 0,45^{\mathrm{ab}}$ \\
Total ALJ & $7,43 \pm 1,80$ & $8,86 \pm 2,22$ & $8,47 \pm 1,54$ \\
C16:1 & $0,61 \pm 0,16$ & $0,69 \pm 0,18$ & $0,62 \pm 0,19$ \\
C18:1 & $11,93 \pm 2,60$ & $12,79 \pm 4,01$ & $11,77 \pm 3,56$ \\
C20:1 & $0,17 \pm 0,00$ & $0,19 \pm 0,01$ & $0,19 \pm 0,05$ \\
Total ALTJT & $12,71 \pm 2,75$ & $13,62 \pm 4,13$ & $12,55 \pm 3,75$ \\
C18:2 & $5,28 \pm 1,17^{\mathrm{c}}$ & $6,61 \pm 1,33^{\mathrm{d}}$ & $6,09 \pm 1,68^{\mathrm{cd}}$ \\
C18:3 & $0,26 \pm 0,06$ & $0,29 \pm 0,07$ & $0,29 \pm 0,09$ \\
Total ALTJG & $5,54 \pm 1,22^{\mathrm{c}}$ & $6,90 \pm 1,39^{\mathrm{d}}$ & $6,38 \pm 1,77^{\mathrm{cd}}$ \\
Total ALTJ & $18,25 \pm 3,94$ & $20,51 \pm 5,52$ & $18,93 \pm 5,42$ \\
\hline
\end{tabular}

Keterangan: superskrip a,b pada baris yang sama menunjukkan berbeda nyata $(\mathrm{P}<0,05) ; \mathrm{c}$, d nyata pada $(\mathrm{P}<0,052)$. ALJ=asam lemak jenuh, ALTJT=asam lemak tidak jenuh tunggal, ALTJG=asam lemak tidak jenuh ganda, ALTJ=asam lemak tidak jenuh.
Tabel 6 menunjukkan bahwa daging itik dengan kulit mengandung asam lemak jenuh (C14:0 dan C16:0), asam lemak tidak jenuh tunggal (C16:1, C:18:1) dan asam lemak tidak jenuh ganda (C18:2 dan C18:3) makin tinggi dengan makin lamanya pemberian pakan perlakuan. Hal ini mencerminkan bahwa makin lama pemberian pakan, makin tua umur itik, penimbunan lemak dan asam lemak makin tinggi. Kondisi ini sesuai dengan pendapat Guo-Bin et al. (2010).

Thio barbituric acid reactive subtances (TBARS). Interaksi antara level pemberian beluntas dengan lama pemberian pakan terhadap nilai TBARS tidak berbeda nyata. Nilai TBARS akibat perlakuan terdapat pada Tabel 7. Level pemberian beluntas tidak berpengaruh terhadap nilai TBARS. Hal ini sejalan dengan hasil penelitian Rababah et al. (2006). Rababah et al. (2006) menunjukkan bahwa nilai TBARS daging dada ayam mentah yang ditambah ekstrak teh hijau yang mengandung antioksidan, yaitu flavonoid, seperti kuersetin dan rutin sebanyak $8 \%$ dari bobot daging atau 2,5\% dari lemak ayam dibandingkan kontrol tidak berbeda, masing-masing sebesar 16,4 dan 16,1 mg malondialdehida per kg.

Tabel 7 menunjukkan bahwa nilai TBARS daging dengan kulit itik pada lama pemberian pakan 5 dan 7 minggu nyata lebih tinggi $(\mathrm{P}<0,05)$ daripada lama pemberian pakan 3 minggu. Nilai TBARS daging dengan kulit itik pada lama pemberian pakan 7 minggu nyata $(\mathrm{P}<0,05)$ lebih tinggi dari nilai TBARS 5 minggu. Hal ini terlihat bahwa makin tingginya nilai TBARS daging dengan kulit itik sejalan dengan makin tingginya kadar lemak dan asam lemaknya (Tabel 4 dan Tabel 6). Ini sesuai dengan hasil penelitian Cherian et al. (2002) bahwa

Tabel 6. Rataan kandungan asam lemak daging itik (Anas plathyrynchos) dengan kulit (\% terhadap bobot daging) pada lama pemberian pakan yang berbeda

\begin{tabular}{lccc}
\hline \multirow{2}{*}{$\begin{array}{l}\text { Jenis asam } \\
\text { lemak }\end{array}$} & \multicolumn{3}{c}{$\begin{array}{c}\text { Lama perian pakan perlakuan } \\
(\mathrm{minggu})\end{array}$} \\
\cline { 2 - 4 } & 3 & 5 & 7 \\
\hline C14:0 & $0,16 \pm 0,01^{\mathrm{a}}$ & $0,16 \pm 0,01^{\mathrm{a}}$ & $0,24 \pm 0,03^{\mathrm{b}}$ \\
C16:0 & $5,05 \pm 0,41^{\mathrm{A}}$ & $5,59 \pm 0,20^{\mathrm{A}}$ & $8,38 \pm 0,84^{\mathrm{B}}$ \\
C18:0 & $2,16 \pm 0,94^{\mathrm{a}}$ & $1,28 \pm 0,22^{\mathrm{b}}$ & $1,75 \pm 0,09^{\mathrm{ab}}$ \\
Total ALJ & $7,37 \pm 0,97^{\mathrm{A}}$ & $7,03 \pm 0,42^{\mathrm{A}}$ & $10,37 \pm 0,96^{\mathrm{B}}$ \\
C16:1 & $0,51 \pm 0,07^{\mathrm{A}}$ & $0,58 \pm 0,06^{\mathrm{A}}$ & $0,83 \pm 0,08^{\mathrm{B}}$ \\
C18:1 & $9,65 \pm 0,32^{\mathrm{A}}$ & $10,87 \pm 0,83^{\mathrm{A}}$ & $15,97 \pm 1,37^{\mathrm{B}}$ \\
C20:1 & $0,18 \pm 0,01$ & $0,16 \pm 0,02$ & $0,20 \pm 0,04$ \\
Total ALTJT & $10,33 \pm 0,39^{\mathrm{A}}$ & $11,61 \pm 0,90^{\mathrm{A}}$ & $16,94 \pm 1,39^{\mathrm{B}}$ \\
C18:2 & $5,29 \pm 0,74^{\mathrm{A}}$ & $5,15 \pm 0,79^{\mathrm{A}}$ & $7,55 \pm 0,81^{\mathrm{B}}$ \\
C18:3 & $0,23 \pm 0,03^{\mathrm{A}}$ & $0,25 \pm 0,03^{\mathrm{A}}$ & $0,35 \pm 0,04^{\mathrm{B}}$ \\
Total ALTJG & $5,52 \pm 0,76^{\mathrm{A}}$ & $5,40 \pm 0,81^{\mathrm{A}}$ & $7,90 \pm 0,85^{\mathrm{B}}$ \\
Total ALTJ & $15,84 \pm 0,99^{\mathrm{A}}$ & $17,01 \pm 1,35^{\mathrm{A}}$ & $24,84 \pm 2,18^{\mathrm{B}}$ \\
\hline
\end{tabular}

Keterangan: superskrip huruf kecil berbeda pada baris yang sama menunjukkan berbeda nyata $(\mathrm{P}<0,05)$; superskrip huruf kapital berbeda pada baris yang sama menunjukkan berbeda sangat nyata $(\mathrm{P}<0,01)$. ALJ=asam lemak jenuh, ALTJT=asam lemak tidak jenuh tunggal, ALTJG=asam lemak tidak jenuh ganda, ALTJ=asam lemak tidak jenuh. 
daging yang mengandung lemak lebih tinggi memiliki nilai TBARS yang lebih tinggi. Kondisi ini menunjukkan bahwa laju oksidasi dipengaruhi oleh kandungan lemak dan asam lemaknya, sejalan dengan hasil penelitian Young et al. (2003) dan Juntachote et al. (2007).

Bau (off-flavor) daging itik. Intensitas bau daging itik dengan kulit hasil perlakuan terdapat pada Tabel 8. Level pemberian beluntas dengan lama pemberian pakan terhadap bau amis (off-odor) daging itik dengan kulit tidak menunjukkan adanya interaksi. Level pemberian beluntas sangat berpengaruh terhadap bau daging itik. Daging itik yang diberi beluntas 1\% dan 2\% sangat nyata $(\mathrm{P}<0,01)$ kurang amis daripada kontrol, dan daging itik yang diberi beluntas $2 \%$ sangat nyata $(\mathrm{P}<0,01)$ kurang amis daripada yang $1 \%$. Hal ini menunjukkan bahwa pemberian beluntas dalam pakan dengan level $1 \%$ dan $2 \%$ mampu mengurangi bau amis daging itik. Hasil penelitian ini mengindikasikan bahwa zat aktif yang terdapat dalam beluntas mempunyai efektivitas sebagai antioksidan sebagaimana dikemukakan Pietta (2000), Burda \& Oleszek (2001), Zieliñska et al. (2001), Beecher (2003), Zang \& Hamauzu (2003), Widyawati (2004), Moskaug et al. (2005), dan Ahmed \& Beigh (2009).

Senyawa fenol, flavonoid, kuersetin dan mirisetin yang terdapat dalam beluntas mempunyai kemampuan menurunkan pembentukan radikal bebas dan menangkap radikal bebas yang dapat menyebabkan terdegradasinya asam lemak. Senyawa volatil penyebab bau (off-odor) (Pazos et al., 2005; Juntachote et al., 2007) yang tidak disukai dari daging itik dan kulit, seperti aldehida, alkohol, keton, asam karboksilat dan hidrokarbon (Hustiany, 2001), menjadi tidak terbentuk dengan terlindunginya asam lemak dari oksidasi. Hal ini diduga yang menyebabkan daging itik dengan kulit yang mendapat beluntas, bau amisnya lebih rendah daripada kontrol (yang tidak mendapat beluntas dalam pakannya). Kondisi ini sejalan dengan hasil analisis asam lemak yang makin tinggi, seperti tercantum pada Tabel 5. Nilai TBARS daging itik dengan kulit pada perlakuan pemberian beluntas seharusnya lebih rendah dari perlakuan tanpa beluntas (kontrol) dengan terlindunginya asam lemak dari oksidasi. Data pada Tabel 7 tampak sejalan, tetapi secara statistik tidak berbeda.

Tabel 7. Nilai thio barbituric acid reactive subtances (TBARS) daging itik (Anas plathyrynchos) berkulit akibat perlakuan (mg/kg malonaldehid)

\begin{tabular}{|c|c|c|c|c|}
\hline \multirow{2}{*}{$\begin{array}{l}\text { Lama } \\
\text { pemberian } \\
\text { pakan } \\
\text { perlakuan } \\
\text { (minggu) }\end{array}$} & \multicolumn{3}{|c|}{ Level pemberian beluntas } & \multirow{2}{*}{ Rataan } \\
\hline & $0 \%$ & $1 \%$ & $2 \%$ & \\
\hline 3 & $1,06 \pm 0,17$ & $1,00 \pm 0,18$ & $0,90 \pm 0,68$ & $0,98 \pm 0,36^{a}$ \\
\hline 5 & $1,49 \pm 0,24$ & $1,44 \pm 0,18$ & $1,38 \pm 0,24$ & $1,44 \pm 0,24^{b}$ \\
\hline 7 & $1,82 \pm 0,03$ & $1,63 \pm 0,24$ & $1,57 \pm 0,12$ & $1,67 \pm 0,17^{c}$ \\
\hline Rataan & $1,39 \pm 0,52$ & $1,37 \pm 0,35$ & $1,33 \pm 0,28$ & \\
\hline
\end{tabular}

Keterangan: superskrip berbeda pada kolom yang sama menunjukkan berbeda nyata $(\mathrm{P}<0,05)$.
Tabel 8. Hasil uji skala tingkat off-odor daging itik (Anas plathyrynchos) berkulit

\begin{tabular}{ccccc}
\hline $\begin{array}{l}\text { Lama } \\
\text { pemberian } \\
\text { pakan }\end{array}$ & \multicolumn{3}{c}{ Level pembelian beluntas } & \\
\cline { 2 - 4 } $\begin{array}{l}\text { perlakuan } \\
\text { (minggu) }\end{array}$ & $0 \%$ & $1 \%$ & $2 \%$ & Rataan \\
\hline 3 & $8,41 \pm 0,18$ & $7,20 \pm 0,24$ & $6,14 \pm 0,63$ & $7,25 \pm 1,14$ \\
5 & $8,66 \pm 0,51$ & $6,61 \pm 0,66$ & $6,04 \pm 0,65$ & $7,10 \pm 1,38$ \\
7 & $8,08 \pm 0,06$ & $6,54 \pm 0,18$ & $5,65 \pm 0,19$ & $7,42 \pm 1,55$ \\
Rataan & $8,38 \pm 0,29^{\mathrm{A}}$ & $6,78 \pm 0,36^{\mathrm{B}}$ & $5,94 \pm 0,26^{\mathrm{C}}$ & \\
\hline
\end{tabular}

Keterangan: superskrip huruf kapital berbeda pada baris yang sama menunjukkan berbeda sangat nyata $(\mathrm{P}<0,01)$.

Tabel 8 menunjukkan bahwa lama pemberian pakan tidak berpengaruh terhadap bau amis daging itik dengan kulit, artinya tingkat bau amis daging itik dengan kulit dari perlakuan lama pemberian pakan 3, 5, dan 7 minggu relatif sama. Ini berarti antara kadar lemak, asam lemak dan nilai TBARS tidak sesuai dengan hasil uji sensori. Kadar lemak, asam lemak, dan nilai TBARS daging dengan kulit itik yang rendah pada lama pemberian pakan 3 minggu, tingkat bau amisnya sama dengan daging itik dengan kulit yang mempunyai kadar lemak, asam lemak dan nilai TBARS yang tinggi pada lama pemberian pakan 7 minggu. Namun demikian, hasil penelitian ini sesuai dengan hasil penelitian Enser (2003). Menurut Enser (2003), sangat sulit untuk mengaitkan antara pengukuran sensori, nilai TBARS dan hasil pengukuran ketengikan secara kimia pada daging masak meskipun keduanya menggunakan metode yang sama. Enser (2003) memberi contoh sebagai berikut: panelis memberikan skor off-odor yang berbeda pada daging babi yang mempunyai nilai TBARS antara 0,5-1,0 $\mathrm{mg}$ per $\mathrm{kg}$ sampel, namun disisi lain, panelis memberi skor off-odor yang sama pada daging yang mempunyai nilai TBARS antara 5,9-11,3.

Tingkat kesukaan panelis. Interaksi antara level pemberian beluntas dengan lama pemberian pakan perlakuan terhadap ting-kat kesukaan konsumen tidak

Tabel 9. Hasil uji hedonik daging itik (Anas plathyrynchos) dengan kulit

\begin{tabular}{ccccc}
\hline \multirow{2}{*}{$\begin{array}{l}\text { Lama } \\
\text { pemberian } \\
\text { pakan }\end{array}$} & \multicolumn{3}{c}{ Level pemberian beluntas } & \\
\cline { 2 - 4 } $\begin{array}{l}\text { perlakuan } \\
\text { (minggu) }\end{array}$ & $0 \%$ & $1 \%$ & $2 \%$ & Rataan \\
\hline 3 & $3,64 \pm 1,37$ & $3,75 \pm 1,36$ & $3,86 \pm 1,29$ & $3,75 \pm 0,11$ \\
5 & $3,65 \pm 1,51$ & $3,92 \pm 1,25$ & $3,87 \pm 1,35$ & $3,81 \pm 0,40$ \\
7 & $3,38 \pm 1,52$ & $3,65 \pm 1,48$ & $3,87 \pm 1,29$ & $3,63 \pm 0,25$ \\
Rataan & $3,56 \pm 0,15^{\text {a }}$ & $3,77 \pm 0,14^{\mathrm{b}}$ & $3,87 \pm 0,01^{\mathrm{b}}$ & \\
\hline
\end{tabular}

Keterangan: Skala hedonik 1=sangat tidak suka; 2=tidak suka; 3=agak tidak suka; $4=$ netral; $5=$ =agak suka; $6=$ suka; $7=$ =sangat suka. Superskrip berbeda pada baris yang sama menunjukkan berbeda nyata $(\mathrm{P}<0,05)$. 
berbeda nyata (Tabel 9). Tingkat kesukaan konsumen terhadap bau daging itik dengan kulit yang diberi pakan tanpa beluntas nyata $(\mathrm{P}<0,05)$ lebih rendah daripada daging itik dengan kulit yang diberi pakan mengandung beluntas $1 \%$ dan $2 \%$. Tingkat kesukaan konsumen terhadap bau daging itik dengan kulit yang diberi pakan mengandung beluntas $1 \%$ dan $2 \%$ tidak berbeda (Tabel 9). Hal ini berarti bahwa beluntas dapat meningkatkan penerimaan konsumen. Daging itik dengan kulit yang mendapat pakan mengandung beluntas $1 \%$ dan $2 \%$ lebih disukai daripada yang diberi pakan tanpa beluntas. Hal ini dapat disebabkan karena bau amis daging itik yang diberi pakan mengandung beluntas sudah berkurang (Tabel 8). Demikian juga lama pemberian pakan perlakuan terhadap tingkat kesukaan konsumen akan daging itik dengan kulit tidak berbeda. Hal ini berarti perbedaan lama pemberian pakan antara 2-4 minggu tidak mempengaruhi tingkat kesukaan konsumen.

\section{KESIMPULAN}

Pemberian beluntas 1\% efektif mencegah terjadinya oksidasi lipida yang ditandai dengan makin tingginya persentase asam lemak, khususnya C18:0, C18:2 dan total C18:2 dan C18:3, berkurangnya bau amis daging itik dengan kulit, dan meningkatnya penerimaan konsumen tanpa berdampak negatif terhadap penampilan itik. Pemberian pakan selama 3 minggu paling efisien tanpa berpengaruh negatif terhadap semua peubah yang diukur.

\section{UCAPAN TERIMA KASIH}

Penulis menyampaikan terima kasih kepada Ditjen Dikti Depdiknas atas bantuan dana, terutama melalui pembiayaan penelitian Hibah Bersaing XIV/2006 dan kepada Kepala dan Tim LPPM IPB yang telah memberi kesempatan untuk melaksanakan penelitian ini. Kepada Ir. Anita Sardiana T., M.Rur.Sc., Ir. Rini H. Mulyono, M.S., Rahmat Slamet, A.Md. (Alm), Eka Koswara, S.Pt., Laeli Komalasari, A.Md., teman-teman dan para panelis yang tidak dapat penulis sebutkan satu per satu, penulis mengucapkan terima kasih atas bantuan dan dukungannya. Semoga Allah SWT selalu melimpahkan rahmat dan hidayahnya. Amien.

\section{DAFTAR PUSTAKA}

Ahmed S. \& S. H. Beigh. 2009. Ascorbic acid, carotenoids, total phenolic content and antioxidant activity of various genotypes of Brassica Oleracea encephala. J. Med. Biol. Sci. 3: 1-8.

AOAC. 1984. Official Methods of Analysis. Association of Official Analylical Chemist Ed ke-14. Virginia.

Barciela J., C. Herrero, S. García-Martín, \& R. M. Peña. 2008. A brief study of the role of selenium as antioxidant. EJEAFChe, 7:3151-3155.

Beecher, G. R. 2003. Overview of dietary flavonoids: Nomenclature, occurrence and intake. J. Nutr. 133: 3248S-3254S

Burda S. \& W. Oleszek. 2001. Antioxidant and antiradical activities of flavonoids. J. Agric. Food Chem. 49:2774-2779.

Cherian G., R. K. Selvaraj, M. P. Geoger, \& P. A. Stitt. 2002. Muscle fatty acid composition and thiobarbituric acid- reactive substances of broiler fed different cultivars of sorghum. Poult. Sci. 81:1415-1420.

Enser, M. 2003. Nutritional effects on meat flavor and stability. In: R. I. Richardson (Ed). Poultry Meat Science. Poultry Science Symposium, Series. Vol. 25. CABI Publishings. New York. pp 197-215

Evans, W. J. 2000. Vitamin E, vitamin C, and exercise. Am. J. Clin. Nutr. 72:647S-652S.

Guo-Bin, C., L. Li-Li, Z. Xue-Yu, W. Ke-Hua, C. Rong, L. De-Qin, \& C. Guo-Hong. 2010. Development rule of intramuscular fat content in chicken. J. Anim. Vet. Adv. 9:297-298.

Hernandez, P., L. Zomeno, B. Arino, \& A. Blasco. 2004. Antioxidant, lipoic acid and proteolytic enzyme activities in pork meat from different genotypes. Meat Sci. 66:525-529.

Huda-Faujan, N., A. Noriham, A. S. Norrakiah, \& A. S. Babji. 2007. Antioxidative activities of water extracts ofs Malaysian herbs. ASEAN Food J. 14:61-68.

Huda-Faujan, N., A. Noriham, A. S. Norrakiah, \& A. S. Babji. 2009. Antioxidative ctivities of plants methanolic extracts containing phenolic compounds. Afr. J. Biotechnol. 8:484-489.

Hustiany, R. 2001. Identifikasi dan karakterisasi komponen off-odor pada daging itik. Tesis. Fakultas Pascasarjana, Institut Pertanian Bogor, Bogor.

IUPAC [International Union of Pure and Applied Chemistry]. 1988. Standard Methods for the Analysis of Oils, Fats, and Derivatives. Blackweil Scientific, Oxford.

Johri, T. S. 2005. Poultry nutrition research in india and its perspective. http://www.fao.org/DOCREP/ARTICLE/ AGRIPPA/659_en00.htm

Juntachote, T., E. Berghofer, S. Siebenhandl, \& F. Bauer. 2007. Antioxidative effects of added dried holy basil and its ethanolic extracts on susceptibility grounds pork to lipid oxidation. Food Chem. 100:129-135.

Kahkonen, M. P. \& M. Heinonen. 2003. Antioxidant activity of anthocyanins and their aglycons. J. Agric. Food Chem. 51: 628-633.

Kiokias, S. \& M. H. Gordon. 2004. Antioxidant properties of carotenoids in vitro and in vivo. Food Rev. Int. 20:99-121.

Kruawan, K. \& K. Kangsadalampai. 2006. Antioxidant activity, phenolic compound contents and antimutagenic activity of some water extract of herbs. Thai J. Pharm. Sci. 30:28-35.

Lin J., S. M. Zhang, K. Wu, W. C. Willett, C. S. Fuchs, \& E. Giovannucci. 2006. Flavonoid intake and colorectal cancer risk in men and women. Am. J. Epidemiol. 164:644-651.

Márquez-Ruiz, G., M. C. García-Martínez, \& F. Holgado. 2008. Changes and effects of dietary oxidized lipids in the gastrointestinal tract. Lipids Insights 2: 11-19

Matjik A. S., \& I. M. Sumertajaya. 2002. Perancangan Percobaan dengan Aplikasi SAS dan Minitab. Jilid 1. IPB Press, Bogor.

Matos, H. R., S. A. Marques, O. F. Gomes, A. A. Silva, J. C. Heimann, P. Di Mascio, \& M. H. G. Medeiros. 2006. Lycopene and B-carotene protect in vivo iron-induced oxidative stress damage in rat prostate. Braz. J. Med. Biol. Res. 39:203-210.

Meilgaard, M., G. V. Civille, \& B. T. Carr. 1999. Sensory Evaluation Techniques. CRC Press, New York.

Miean, K. H. \& S. Mohammed. 2001. Flavonoid (myricetin, quercetin, kaempferol, luteolin and apigenin) content of edible tropical plants. J. Agric. Food Chem. 49: 3106-3112.

Min, B., J. C. Cordray, \& D. U. Ahn. 2010. Effect of NaCl, myoglobin, $\mathrm{Fe}(\mathrm{II})$, and $\mathrm{Fe}(\mathrm{III})$ on lipid oxidation of raw and cooked chicken breast and beef loin. J. Agric. Food Chem. 58:600-605. 
Moskaug, J. Ø., H. Carlsen, M. C. W. Myhrstad, \& R. Blomhoff. 2005. Polyphenols and glutathione synthesis regulation. Am. J. Clin. Nutr. 81(suppl):277S-83S.

Muika, B., B. Lendl, A. Molina-D'1az, \& M. J. Ayora-Ca nada. 2005. Direct monitoring of lipid oxidation in edible oils by Fourier transform Raman spectroscopy. Chem. Phys. Lipids 134:173-182.

Padayatty, S. J, A. Katz, Y. Wang, P. Eck, O. Kwon, J-H. Lee, S. Chen, C. Corpe, A. Dutta, S. K. Dutta, \& M. Levine. 2003. Review. Vitamin $C$ as an antioxidant: Evaluation of its role in disease prevention. J. Am. Coll. Nutr. 22:18-35.

Panovskai, T. K., S. Kulevanova, \& M. Stefova. 2005. In vitro antioxidant activity of some Teucrium species Lamiaceae). Acta Pharm. 55:207-214.

Pazos M., J. M. Gallardo, J. L. Torres, \& I. Medina. 2005. Activity of grafe polyphenols as inhibitor of the oxidation of fish lipids and frozen fish muscle. Food Chem. 92:547-557.

Pietta P. G. 2000. Flavonoids as antioxidant. Reviews. J. Nat. Prod. 63:1035-1042.

Pisulewski, P. M. 2005. Nutritional potential for improving meat quality in poultry. Anim.1 Sci. Pap. Rep. 23:303-315.

Rababah T., N. S. Hettiarachchy, R. Horax, M. J. Cho, B. Davis, \& J. Dickson. 2006. Thiobarbituric acid reactive substances and volatile compounds in chicken breast meat infused with plant extracts and subjected to electron beam irradiation. Poult. Sci. 85:1107-1113.

Savatović, S. M., G. S. Ćetković, S. M. Đilas, V. T. Tumbas, J. M. Čanadanović-Brunet, D. D. Četojević-Simin, \& A. I. Mandić. 2008. Antioxidant and antiproliferative activity of granny smith apple pomace. BIBLID: 1450-7188 (39): 201212. APTEFF, 39, 1-212 (2008) DOI: 0.2298/APT0839201S

Scalbert A. \& G. Williamson. 2000. Dietary intake and bioavailability of polyphenols. J. Nutr. 130:2073S-2085S.

Schewe T. \& H. Sies. 2003. Flavonoids as protectants against prooxidant enzyme. Research monographs: Flavonoids and prooxidant enzymes. Institut für Physiologische Chemie I; Heinrich-Heine-Universität Düsseldorf. http:// www.uni-duesseldorf.de/WWW/MedFak/PhysiolChem/ index.html. [18 September 2008].
Shetty, K., O. F. Curtis, R. E. Levin, R. Witkowsky, \& W. Ang. 1995. Prevention of vitrification associated with in vitro shoot culture of oregano (Origanum vulgare) by Pseudomonas spp. J. Plant Physiol. 147:447-451.

Stamet, D. S., M. K. Mahmud, Muhilal, D. Fardiaz, \& J. P. Simarmata. 1990. Pedoman Analisis Zat Gizi. Departemen Kesehatan Republik Indonesia. Direktorat Bina Gizi Masyarakat dan Pusat Penelitian dan Pengembangan Gizi, Bogor.

Tang, L., Y. Zhang, Z. Qian, \& X. Shen. 2000. The mechanism of Fe2+-initiated lipid peroxidation in liposomes : the dual function of ferrous ions, the roles of the pre-existing lipid peroxides and the lipid peroxyl radical. Biochem. J. 352: 27-36

Traithip, A. 2005. Phytochemistry and antioxidant activity of Pluchea indica. Thesis. Mahidol University.

Widyawati, P. S. 2004. Aktivitas antioksidan tanaman herba kemangi (Ocimum basilicum Linn) dan beluntas (Pluchea indica Less) dalam sistem model asam linoleat. Laporan Penelitian.Fakultas Pertanian, Universitas Katolik Widya Mandala, Surabaya.

Yoon, J. H., M. S. Lee, \& J. H. Kang. 2010. Reaction of ferritin with hydrogen peroxide induces lipid peroxidation. BMB Reports:219-224.

Young, K. H., O-H. Kim, \& M-K. Sung. 2003. Effects of phenol-depleted and phenol-rich diets on blood markers of oxidative stress, and urinary excretion of quercetin and kaempferol in healthy volunteers. J. Am Coll. Nutr. 22:217-223

Zhang, D. \& Y. Hamauzu. 2003. Phenolic compounds, ascorbic acid, carotenoids and antioxidant properties of green, red and yellow bell peppers. J. Food Agric. Environ. 1:22-27. http://www.aseanfood.info/Articles/11019980.pdf. [13 April 2010].

Zielińska, M., A. Kostrzewa, E. Ignatowicz, \& J. Budzianowski. 2001. The flavonoids, quercetin and isorhamnetin 3-0-acylglucosides diminish neutrophil oxidative metabolism and lipid peroxidation. Acta Biochim. Pol. 48:183-189. 